\title{
Formative E-Assessment in PAD College English Class
}

\author{
Yang Yanping ${ }^{1, *}$, Cui Zhenhua ${ }^{2}$ \\ 1\&2Management Department, Ordos Institute of Technology, Ordos, 017100, Inner Mongolia, China \\ *Corresponding author. Email: eedsglxy@163.com
}

\begin{abstract}
This article reports on the implementation of formative e-assessments in a Presentation-Assimilation-Discussion (PAD) College English class taken by second-year students after 3 terms. The aim is to measure the effectiveness of the formative e-assessments with reference to the student voice. Students engaged with the formative e-assessments and the data gathered via questionnaires show that students perceived that formative e-assessments helped them to develop good learning habits; encouraged autonomous learning and promoted their learning and understanding. The findings also allowed academics to reflect on the benefits of adopting formative e-assessments in the PAD class to foster student engagement.
\end{abstract}

Keywords: Formative e-assessment, effectiveness, Presentation-Assimilation-Discussion (PAD), College English

\section{PRESENTATION-ASSIMILATION- DISCUSSION (PAD) CLASS}

Presentation-Assimilation-Discussion (PAD) Class, or Bisection Classroom, is a teaching approach proposed by Zhang Xuexin, a professor of psychology at Fudan University, China in 2014. The PAD class has integrated the advantages of both "teacher-centred" and "studentcentred" teaching models. It redefines the classroom and the teacher-student relationship through integrating traditional Chinese educational wisdom with learning theories in educational psychology and modern teaching theories in pedagogy [1]. The teaching approach emphasizes the internalization process and combines organically teacher's teaching with students' discussing.

The core of the PAD Class is to divide the class time into two parts: one part for teachers' presentation and evaluation, and the other for students' in-class output after their task-based after-class assimilation [1]. PAD Class emphasizes the teacher's guiding role in teaching, and at the same time, it also draws on the advantages of classroom discussions in that it focuses on the interaction among students and teachers. What's more, PAD Class encourages students to learn independently and autonomously under the guidance of the teacher. In our college English class, the authors followed the principles of PAD Class, teachers' made presentation at first, students had assimilative learning after, and then students had group or class discussion under the teacher' $s$ instruction. Owing to the limited class time, the connection between the teachers' teaching and students' learning were linked by formative e-assessment.

\section{FORMATIVE E-ASSESSMENT}

Formative assessment has expanded over the past three decades in response to traditional measurement, in which assessment is solely about producing accurate estimations of students' learning to monitor or report on progress. In the measurement tradition, formative assessment is often explained as a contrast to summative assessment. Formative assessment is about low-stakes testing, whereas summative assessment concerns highstakes testing [2]. However, assessments with a summative or a formative purpose are both used to produce inferences about students' learning. Assessments become formative when the inference about a student's learning is "elicited, interpreted, and used by teachers, learners, or their peers, to make decisions about the next steps in instruction that are likely to be better, or better founded, than the decisions they would have taken in the absence of the evidence that was elicited' [3]. In other words, when assessment is looked as a formative practice, teachers and the students have their roles realized in the process of learning. In practice, formative assessment is seen as a cyclical program of high and low-stake tasks in which students are actively involved both as assessee and/or assessor [2]. 
The accelerated evolution of the information and communication technologies has been fostering a change of the teacher's role from a communicator of the student's mark to the participant of an open system in which teachers and students get deeply involved in the learning process and develop online assessment skills. Modern communicative technologies have turned the mobile terminals into essential tools in improving current assessment strategies in higher education of all levels in China, especially after the Covid-19 pandemic in 2020. E-assessment is playing an increasingly important role in transforming traditional class into the mixed online and offline classes; therefore, it is making a significant impact on the college teaching and learning. Comparing it with face-to-face context assessment, online assessments display different qualities, such as timeliness, conciseness, and effectiveness, considering the asynchronous interactivity involved both teachers and learners. This fact has led teachers to rethink their pedagogy to perform assessment activities that support meaningful learning in online environment. This paper aims to know the satisfactory of College English learners on the e-assessment in PAD class.

\section{METHODOLOGICAL APPROACH}

This paper analyses the attitude of students in eassessment activities centered in a PAD College English course and their perception about this process, the following research questions are considered:

How students appreciate the e-assessment strategies of the PAD Class college English?

What do these assessment strategies contribute to the English learning process?

We developed a qualitative research; the design of the research is explained in the following sections.

\subsection{The teaching process}

The research is conducted at Ordos Institute of Technologies, in which the students had an online college English PAD courses for a full spring term in 2020 because of the Covid-19 pandemic and then they had mixed online and offline College English PAD classes for two terms before the survey was conducted. The experience presented in this paper concretely focuses on College English, a compulsory course to build foreign language knowledge step by step. In order to develop their language skills, students follow the process of the subject based on the subsequent phases under the concept of PAD, as shown in Figure 1 [4].

Firstly, English teachers explain the key and difficult contents of each unit in face-to-face class, to specify the difficult language points and culture merits and to help students understand new language knowledge. Then, before the next week's class, students would have enough time to assimilate what has been presented, and to make preparation for the in-class discussion. Based on the corresponding tasks given by the teacher or aroused in the former discussion, students can have time to internalize what they have learned and improve the output in the further discussion. The help of teachers on the difficult points in the unit at the presentation degrades the difficulty in students' self-learning process. After the leaners' assimilation or self-learning, they come to the online group discussion before the in-class discussion the following week. In the online discussion, sometimes supervised by the teacher, the students can share their learning experiences and points of view with the group members, check how much they have learned and solve problems together, which help them learn from their peers and nurture their autonomous learning abilities.

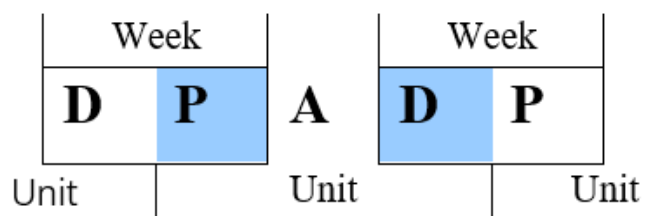

Figure 1 The teaching and learning procedures of online PAD College English class

Note: $\mathrm{P}=$ Presentation $\quad \mathrm{A}=$ Assimilation $\quad \mathrm{D}=$ Discussion

The online-discussion will get instant feedback from the peer students through Wechat, an instant chatting system; the writing and translating works would get instant feedback from Unipus, a professional learning platform; and the listening and speaking assignment will be judged by the system of WeLearn, another professional learning system. All learning process is under the supervision of the teacher, who subsequently gives nudges to individuals or groups on their performance. The results of the assessment are open to all students, they can check their mark after each hand-in, and they can redo most work until their satisfaction before the deadline.

\subsection{The role of teacher and students in the e- assessment process}

In order to understand the role of students during the e-assessment process in PAD college English, it is necessary to describe the role of the teacher during this process. During the development of the course, the teacher carries out a process and final assessment with the help of the learning platforms' automatic feedback. The teacher monitors and assesses the online work developed in each group or individual during the process in order to improve their language skills and autonomous learning abilities. In this assessment, the active role of the students is quite relevant, since the self-assessment they developed in each phase of the language learning is one of the elements that determine the teacher's assessment on their work, including the online assessment or e-assessment. 
The process assessment is finished with both individual and group feedback: individual feedback is based on the observation of the participation of each student within the group in their group discussion, plus his/her individual works both online and offline; and the group one is based on the monitoring of the group's dynamics and processes at class or video record of their group discussion posted to the teacher. In the final assessment, the teacher assesses the final product of each learning phase following the predetermined criteria shown at the beginning of the course. Moreover, a reflection about the PAD College English course is carried out at the end of the term, based on an interactive process among the members of the group.

The participation, available at any time, in the eassessment process provides students with an awareness of their grade of language acquisition, thereby allowing them to be an assessment agent of their own learning process from different perspectives. In consequence, eassessment becomes, within the PAD college English course syllabus, a very valuable resource to foster students' implication in their own learning, from both the individual and group/class perspective. An online assessment process is set in the past terms. The online assessment process becomes inseparable to the PAD college English course since it is necessary for the students to get internal peer evaluation and for the teacher to collect data on the group or individual's performance in the learning process, in which, both teachers and students are participants and evaluators.

\subsection{Data gathering}

In order to gather the data, a questionnaire based on former researches [5] [6] [7] was designed and applied at the end of the autumn term of 2020-2021. The questionnaire was printed in Chinese. There were 15 items in the questionnaire to learn the learners' attitude towards the formative assessment in PAD college English course from four dimensions as: self-confidence establishment, learning motivation stimulation, learning habits development and communication strengthening.

Before the delivery of the questionnaire, the reliability of the items was pre-tested. As can be seen from Table I, the value of the confidence coefficient is 0.984 , which is greater than 0.9 , which indicates that the reliability quality of the research data is very high. The statements were rated on a five-point Likert-scale, ranging from $1=$ "strongly disagree" or "not at all true of me" to $5=$ "strongly agree" or "very true of me".

TABLE 1. Cronbach Alpha

\begin{tabular}{lll}
\hline $\mathrm{N}$ of Items & $\mathrm{n}$ & Cronbach $\mathrm{a} \square$ \\
\hline 15 & 59 & 0.984 \\
\hline
\end{tabular}

The electronic questionnaires were posted to participants online so that they can answer them with their computers or smartphones. 66 students majored in computer science in the authors' college answered the questionnaire and 59 responses were valid after excluding the invalid questionnaires with incomplete answers.

\section{DATA ANALYSIS AND DISCUSSION}

To test students' attitudes on the e-assessment after 3 terms online assessment at different levels, the questionnaire was designed on three aspects as selfconfidence establishment, learning habits development and communication strengthening. The descriptive values, as shown in table 2 , indicated most students accept the formative e-assessment as a helpful strategy.

TABLE 2. The descriptive values of the items

\begin{tabular}{|c|c|c|}
\hline & Means & St. \\
\hline $\begin{array}{l}\text { I usually reflect, reevaluate, } \\
\text { and adjust after unit-learning } \\
\text { (1) }\end{array}$ & 3.78 & 1.345 \\
\hline $\begin{array}{l}\text { I prefer to the mixed online and } \\
\text { offline PAD English course (2) }\end{array}$ & 3.86 & 1.309 \\
\hline $\begin{array}{l}\text { The formative e-assessment } \\
\text { strengthens my understanding } \\
\text { (3) }\end{array}$ & 3.72 & 1.31 \\
\hline $\begin{array}{l}\text { The formative e-assessment } \\
\text { helps me learn more and better } \\
\text { (5) }\end{array}$ & 3.76 & 1.318 \\
\hline $\begin{array}{l}\text { The formative e-assessment } \\
\text { pushes me review regularly (6) }\end{array}$ & 3.72 & 1.31 \\
\hline $\begin{array}{l}\text { I have a better understanding } \\
\text { from the feedback of the e- } \\
\text { assessment. ( } 7 \text { ) }\end{array}$ & 3.56 & 1.593 \\
\hline $\begin{array}{l}\text { The formative e-assessment } \\
\text { helps me foster a good learning } \\
\text { habit (11) }\end{array}$ & 3.64 & 1.396 \\
\hline $\begin{array}{l}\text { The formative e-assessment } \\
\text { makes me use my time fully } \\
\text { (12) }\end{array}$ & 3.68 & 1.421 \\
\hline $\begin{array}{l}\text { The formative e-assessment } \\
\text { give me confidence in learning } \\
\text { (13) }\end{array}$ & 3.82 & 1.335 \\
\hline $\begin{array}{l}\text { The formative e-assessment } \\
\text { clarifies my learning motivation } \\
\text { (14) }\end{array}$ & 3.58 & 1.401 \\
\hline $\begin{array}{l}\text { The formative e-assessment } \\
\text { improves communicative skills } \\
\text { online. (15) }\end{array}$ & 3.64 & 1.425 \\
\hline
\end{tabular}

The students established self-confidence (3.82) in the formative e-assessment, as more than $87 \%$ students agreed or fully agreed with "The formative e-assessment give me confidence in learning". They became clearer in their learning motivation (3.58), fostered a better learning habit on regular review (3.72) and adjustment (3.78) on their learning strategies. At the same time their online communicative skills (3.64) were strengthened in the eassessment too. 
Then the correlation among the parameters of the confidence from e-assessment in PAD College English and the parameters of learning habits was analysed by Pearson test, as shown in Table III. From Table 3, we can see the parameter of the confidence establishment and the parameters on learning habits have a positive relationship in the 90 percent confidence interval, and vice versa. An increase of the variables above will give students incentive of learning. The formative e-assessment will help students to reflect, reevaluate, and adjust their learning plan and learning strategies after learning ang assessing each unit. The feedback from the e-assessment will also encourage students to review regularly, to write, translate read and listen more carefully before handing in their homework. The formative e-assessment has turn every step of learning into the process of evaluation, so the students can make full use of their free time in English learning because they take every step of learning more seriously.

TABLE 3. Pearson Correlation

\begin{tabular}{ll}
\hline & \multicolumn{1}{c}{$\begin{array}{c}\text { The formative } \\
\text { e-assessment } \\
\text { gives me } \\
\text { confidence in } \\
\text { learning (13) }\end{array}$} \\
\hline $\begin{array}{l}\text { I usually reflect, reevaluate, and } \\
\text { adjust after unit-learning. (1) }\end{array}$ & $0.750^{* *}$ \\
$\begin{array}{l}\text { The formative e-assessment } \\
\text { strengthens my understanding. (3) }\end{array}$ & $0.776^{* *}$ \\
$\begin{array}{l}\text { The formative e-assessment helps } \\
\text { me learn more and better. (5) } \\
\text { The formative e-assessment pushes } \\
\text { me review regularly. (6) }\end{array}$ & $0.682^{* *}$ \\
$\begin{array}{l}\text { I have a better understanding from } \\
\text { the feedback of the e-assessment. } \\
\text { (7) }\end{array}$ & $0.682^{* *}$ \\
$\begin{array}{l}\text { I rewrite my writing or translating } \\
\text { homework before hand-in. ( } 8) \\
\text { I relisten until my satisfaction before } \\
\text { hand-in. ( } 9 \text { ) }\end{array}$ & $0.816^{* *}$ \\
$\begin{array}{l}\text { The e-assessment makes me put } \\
\text { my free time into learning. (12) }\end{array}$ & $0.768^{* *}$ \\
\hline
\end{tabular}

${ }^{*} p<0.05{ }^{* *} p<0.01$

\section{CONCLUSION}

This paper added to our understanding of the student experience of regular formative e-assessments in PAD College English course and allowed us to judge their effectiveness. It introduced PAD College English Class and formative e-assessments, built on the informed views of teachers attempting to improve student learning. The investigation mainly focused on the students' attitude to the formative e-assessment in their PAD College English course. Based on the results, there is evidence of the benefits of introducing regular formative e-assessment in the past three terms. The results show the students regarded the regular formative e-assessment were effective at:

1. helping them develop good learning habits;

2. encouraging autonomous learning;

and 3. bettering a student's English level of learning and understanding

These are all important indicators of student engagement and the move towards becoming independent learners.

Reflection on the students' comments also provides supporting evidence which suggests fostering student engagement in PAD college English class has the potential to help students build the skills required to become more reflective and autonomous learners. The study makes it clear that the best structure for e-assessments needs careful planning.

This article has focused on listening to the student voice and reporting on that voice in PAD college English class. Of course, the paper had several limitations. To address these limitations, we suggest future research should consider: Using a variety of aspects for formative e-assessments, such as including peer evaluating in group works and individual improvement measured by a thirdparty test; The timely feedback information from both peers and teachers in relation to student expectations; The time teachers have to spend on developing and responding to formative e-assessments should be encouraged. Addressing these issues would help contributing our efforts to developing effective formative e-assessments that are fit for purpose and confirm their place within higher education with modern information technology.

\section{ACKNOWLEDGMENT}

This paper is sponsored by Chinese Academy of Social Science in Inner Mongolia Autonomous Region (YZX2019-31)

\section{REFERENCES}

[1] Zhang Xuexin. The new wisdom of Chinese education in bisection classroom [M]. Beijing: Science Press, 2017.

[2] Martijn Leenknecht, Lisette Wijnia, Martine Köhlen, Luke Fryer, Remy Rikers \& Sofie Loyens (2020) Formative assessment as practice: the role of students' motivation, Assessment \& Evaluation in Higher Education, DOI: 10.1080/02602938.2020.1765228.

[3] Black, P., and D. Wiliam. 2018. "Classroom Assessment and Pedagogy." Assessment in Education: Principles, Policy \& Practice 25 (6): 551. DOI:10.1080/0969594X.2018.1441807. 
[4] Cui Zhenhua \& Yang Yanping. 2021. Research on Effects of Online PAD Class on Autonomous Learning for College English Learners Based on Pearson Test. 2021 International Conference on Big Data and Informatization Education (ICBDIE)

[5] Suzanne McCallum \& Margaret M. Milner (2020): The effectiveness of formative assessment: student views and staff reflections, Assessment \& Evaluation in Higher Education, DOI: 10.1080/02602938.2020.1754761

[6] Carina Granberg, Torulf Palm, Björn Palmberg, A case study of a formative assessment practice and the effects on students' self-regulated learning, Studies in Educational Evaluation, Volume 68, 2021, 100955, ISSN 0191-491X, https://doi.org/10.1016/j.stueduc.2020.100955.

[7] Christian Brandmo, Ernesto Panadero \& Therese N. Hopfenbeck (2020) Bridging classroom assessment and self-regulated learning, Assessment in Education: Principles, Policy \& Practice, 27:4, 319331, DOI: 10.1080/0969594X.2020.1803589 